\title{
Preferences of farmed blue foxes for platforms, nestbox and cage floor
}

\begin{abstract}
Hannu Korhonen and PaAvo Niemelä
Korhonen, H. \& Niemelä, P. 1994. Preferences of farmed blue foxes for platforms, nestbox and cage floor. Agricultural Science in Finland 3: 467-472. (Agricultural Research Centre of Finland, Fur Farming Research Station, FIN-69100 Kannus, Finland.)

A preference test system was devised to assess the preferences of farm-raised, juvenile blue foxes for six various types of resting platforms, including nestbox roof, and for nestbox and cage floor. The results showed that platform use was low since the test foxes preferred the cage floor. The amount of previous individual platform usage did not affect preference. However, foxes originating from groups with a high amount of previous platform use also had the highest amount of platform usage in the test situation. Of all the platforms, the nestbox roof was preferred the most. Although the location of the platform in the present test situation was found to affect preference, it was difficult to finally separate the real effects of platform location and type. No relationship was found between temperature and use of the platforms or nestbox. On the basis of the present results we may conclude that platforms are not actually necessary for foxes during winter period.
\end{abstract}

Key words: platform use, farmed fox, environmental enrichment, welfare

\section{Introduction}

The Standing Committee of the European Convention on the Protection of Animals Kept for Farming Purposes has issued a recommendation that each weaned fox shall have a whole-year shelter, either a resting platform or nestbox, but preferably both available (European Convention 1991). However, compliance with the recommendation is problematic, due to the lack of one particular approved or even recommended construction model. Furthermore, according to the observations of some recent studies, foxes do not necessarily utilize resting platforms to a large extent (HARri et al. 1991, JePpesen and Pedersen 1991, PEDERSEN and JEPPESEN 1993), and platform usage is characterized by large individual variation, depending on the construction model, for instance
(KoRHONEN and NiEMELÄ 1993a,b). Therefore, it is somewhat difficult to draw the right conclusions as to what constitutes the best platform type and vice versa. In this regard, it would probably be wiser to let the fox decide for itself.

To this end, the present authors devised a preference test system that gives the animal the possibility to selectively seek out the platform type it prefers. The present paper reports the results of such a preference test performed on farmed blue foxes (Alopex lagopus).

\section{Material and methods}

\section{Subjects, and managements before testing}

The experiments were carried out at the Fur Farming Research Station of Kannus in western Fin- 


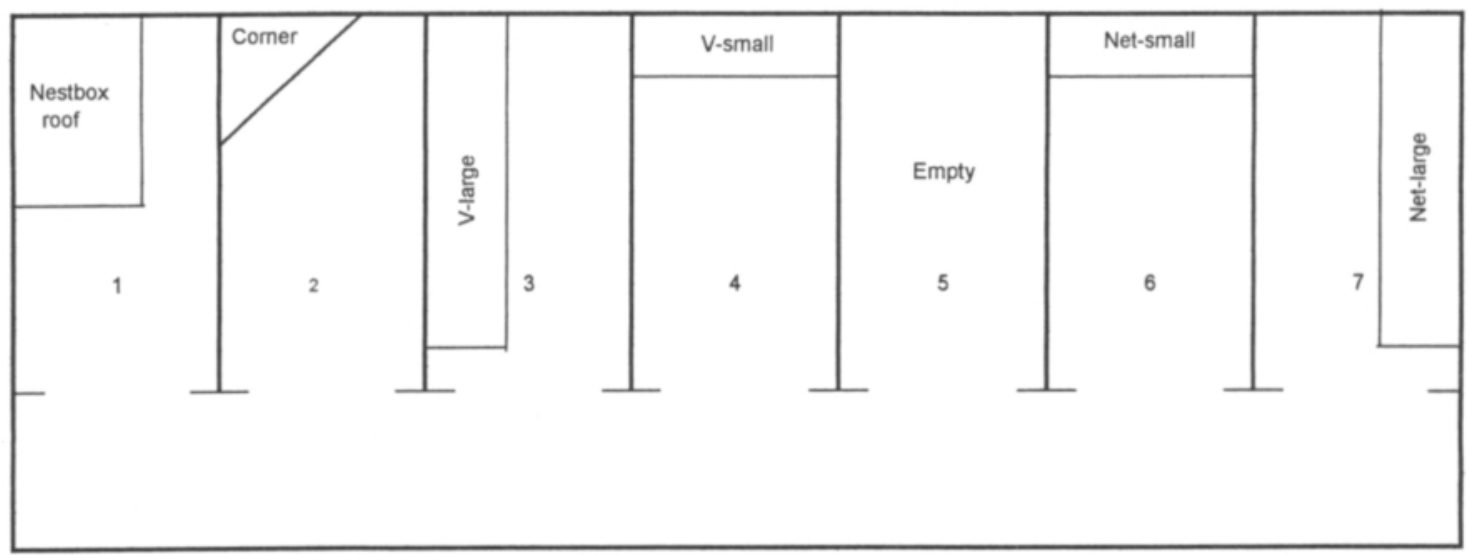

Fig.1. Schematic picture of the preference test cage system.

land. Three experimental groups named as follows were tested: (1) V-large, (2) Net-large and (3) Corner. Each group consisted of 10 juvenile males. Before preference testing, the animals in these groups were housed in cages with the platform type above mentioned between Aug. 2thNov. 11th. During this time, their daily platform useage was monitored by scanning observations made each workday (Monday-Friday) of the month, three times a day (8 a.m., 12 a.m. and 3 p.m.). During the scan sampling the investigator slowly and quietly walked past the row of cages and manually recorded the location of each fox. If the fox fled at the approach of the investigator, the location of the fox before it fled was recorded (PEDERSEN and JePPESEN 1993, KoRHONEN and NIEMELÄ 1993a,b).

\section{Preference test system}

A special cage system was designed for testing the foxes' preference for different platform types (Fig.1). The test system was comprised of seven small separate cage sections $(75 \mathrm{~cm}$ wide $\times 107$ $\mathrm{cm}$ long) situated inside one large cage $(159 \mathrm{~cm}$ wide $x 525 \mathrm{~cm}$ long). This arrangement gave the test animal free access from the large cage into each of the smaller cages. The shelter constructions in the smaller cages measured from left to right as follows: (1) a nestbox, measuring $70 \mathrm{~cm}$ long x $40 \mathrm{~cm}$ wide $\times 40 \mathrm{~cm}$ high,surface area $0.280 \mathrm{~m}^{2}$, (2) a triangular, flat corner wooden platform; $65 \mathrm{~cm} \times 91 \mathrm{~cm}$, surface area $0.205 \mathrm{~m}^{2}$, (3) a large, V type wooden platform; $103 \mathrm{~cm}$ long x $30 \mathrm{~cm}$ wide, surface area $0.309 \mathrm{~m}^{2}$, (4) a small, $\mathrm{V}$ type wooden platform; $52 \mathrm{~cm}$ long $\mathrm{x} 30$ $\mathrm{cm}$ wide, surface area $0.156 \mathrm{~m}^{2}$, (5) an empty cage, with no platform or nestbox, (6) a small wire mesh net platform; $52 \mathrm{~cm}$ long x $30 \mathrm{~cm}$ wide, surface area $0.156 \mathrm{~m}^{2}$, and (7) a large, wire mesh net platform; $103 \mathrm{~cm}$ long x $30 \mathrm{~cm}$ wide, surface area $0.309 \mathrm{~m}^{2}$. The ceiling was $23 \mathrm{~cm}$ from the cage roof in each type. Platform locations were randomly chosen.

The tests were carried out during November 16th-February 23rd. Each fox was made accustomed to the test situation six days before the actual test which lasted 8 hours ( 8 a.m. -4 p.m). Preferences were recorded by video camera equipment (Bische CCD video camera 7240, Koyo monitor, Bische UB-480 time lapse video recorder). To minimize the effects of time of month (season), the animals were tested in successive series, each series including one animal from each group.

\section{Statistics}

All statistical analyses were performed using the Statistical Analysis Systems Institute (SAS) pro- 
cedures (SAS 1988). Because of marked deviation from normal distribution, the differences between the means of resting place use were tested with the Kruskal-Wallis tests, and with the MannWhitney U-tests when comparing two groups. Effects of platform location and original platform group on choice of resting platform as well as effects of the month on the amount of use in the test were analyzed by analysis of variance (ANO$\mathrm{VA}$ ) in the general linear models (GLM) procedure. This data was normalized by arc-sine transformation. Regression analysis was used to calculate the dependence of daily platform use on ambient air temperature. The results are presented as the mean \pm standard error (SE).

\section{Results}

Table 1 shows the platform use of the experimental groups before the preference test. In the corner group, platform use remained rather low throughout the experiments, although some increasing trend was evident towards October/November. In the V-large group, a decreasing trend in platform usage was noted from August until November, but the differences between months were statistically non-significant. Only in the Net-
Table 1. Percentages of observations (mean \pm SE) of platform use by foxes in the platform type groups before preference testing. $\mathrm{N}=10$ males in each group. Data are based on visual scanning observations. Means with different superscript letters are significantly $(p<0.001)$ different between the groups (Kruskal-Wallis test/Mann-Whitney U-test).

\begin{tabular}{lccc}
\hline & V-large & Net-large & Corner \\
\hline August & $51.8 \pm 2.0^{\mathrm{a}}$ & $61.3 \pm 2.0^{\mathrm{b}}$ & $2.3 \pm 0.6^{\mathrm{c}}$ \\
September & $51.5 \pm 2.0^{\mathrm{a}}$ & $51.5 \pm 2.0^{\mathrm{a}}$ & $4.7 \pm 0.8^{\mathrm{c}}$ \\
October & $46.6 \pm 2.1^{\mathrm{a}}$ & $34.7 \pm 2.0^{\mathrm{b}}$ & $6.9 \pm 1.1^{\mathrm{c}}$ \\
Noverber & $44.6 \pm 3.0^{\mathrm{a}}$ & $32.5 \pm 2.8^{\mathrm{b}}$ & $6.4 \pm 1.5^{\mathrm{c}}$ \\
\hline
\end{tabular}

large group was the decrease in use from August to November significant $(\mathrm{p}<0.01)$. Platform use was significantly $(\mathrm{p}<0.001)$ lower in the corner group than in the other two groups.

The results of the preference testing are presented in Tables 2 and 3 . The use of resting platforms was rather low in general because the foxes significantly preferred the cage floor, for either sleeping $(\mathrm{p}<0.001)$ or locomotor activity $(\mathrm{p}<0.001)$.

The most favoured platforms were the nestbox roof, V-small and Net-large. These platforms were located either at the end of the total test cage

Table 2. Distribution of activity forms and use of different resting platforms during the tests. Data are based on video recordings and expressed as percentages of total activity per $8 \mathrm{~h}$ (mean $\pm \mathrm{SE}$ ). V-large, Net-large and Corner in the upper row are the original groups from which the tested animals were taken. $\mathrm{N}=10$ males in each group. The groups did not differ significantly from each other in any of the cases (Kruskal-Wallis test).

\begin{tabular}{lrrrr}
\hline & V-large & Net-large & Corner & Mean \\
\hline On nestbox roof & $10.9 \pm 8.4$ & $4.3 \pm 2.2$ & $2.5 \pm 2.2$ & $5.9 \pm 2.8$ \\
Inside nestbox & $0.4 \pm 0.1$ & $0.4 \pm 0.2$ & $7.9 \pm 7.0$ & $2.9 \pm 2.4$ \\
On corner & $0.1 \pm 0.1$ & $0.1 \pm 0.0$ & $0.2 \pm 0.2$ & $0.1 \pm 0.1$ \\
On V-large & $0.1 \pm 0.1$ & $0.2 \pm 0.1$ & $0.1 \pm 0.0$ & $0.1 \pm 0.0$ \\
On V-small & $3.8 \pm 3.4$ & $6.0 \pm 3.9$ & $0.7 \pm 0.5$ & $3.5 \pm 1.7$ \\
In empty cage & $0.6 \pm 0.3$ & $0.7 \pm 0.3$ & $0.6 \pm 0.1$ & $0.6 \pm 0.1$ \\
On Net-small & $1.1 \pm 1.1$ & $0.1 \pm 0.1$ & 0 & $0.4 \pm 0.4$ \\
On Net-large & $5.4 \pm 3.3$ & $3.3 \pm 3.1$ & 0 & $2.9 \pm 1.5$ \\
Sleeping on floor & $35.7 \pm 7.2$ & $43.5 \pm 9.0$ & $45.0 \pm 4.8$ & $41.4 \pm 4.1$ \\
Locomotor activity & $41.8 \pm 4.5$ & $41.4 \pm 5.8$ & $42.9 \pm 4.7$ & $42.1 \pm 2.8$ \\
\hline
\end{tabular}

a empty cage excluded 
Table 3. Comparison of platform use (percentages of observations per $8 \mathrm{~h}$, mean $\pm \mathrm{SE}$ ) between experimental groups in the preference test. Means with different superscript letters are significantly $(\mathrm{p}<0.05)$ different between the groups (Kruskal-Wallis test/Mann-Whitney U-test).

\begin{tabular}{lrrr}
\hline & V-large & Net-large & Corner \\
\hline All platforms & $21.4 \pm 8.6^{\mathrm{a}}$ & $13.9 \pm 6.2^{\mathrm{ab}}$ & $3.6 \pm 2.2^{\mathrm{b}}$ \\
Without roof & $10.5 \pm 4.7^{\mathrm{a}}$ & $9.8 \pm 6.1^{\mathrm{a}}$ & $1.0 \pm 0.7^{\mathrm{a}}$ \\
\hline
\end{tabular}

(nestbox roof, Net-large) or in the middle (Vsmall; see Fig.1). The location (end vs. middle vs. other) had a statistically significant $(\mathrm{p}<0.05)$ effect on the use, but, the month (i.e. time of season) in which the tests were performed had no significant effect.

The foxes did not show significant preference for the platform types which they had used previously before the test period. In addition, the amount of earlier platform usage did not explain the frequency of individual platform use in the preference test. At the group level, however, group V-large, which had the highest amount of previous platform use, also had the highest frequency of use in the preference test and, correspondingly, the corner group had the lowest amount of use both before and during the tests.

Platform use did not differ between groups if the use of the nestbox roof was excluded from the preference test (Table 3). However, if all platforms were included, the difference became significant because the use of the nestbox roof was highest in the V-large group.

The daily temperature during the tests ranged from +3 to $-23^{\circ} \mathrm{C}\left(\right.$ mean $\left.-10.7 \pm 1.3^{\circ} \mathrm{C}\right)$. However, no statistically significant relationships were found between platform use and temperature, nor between nestbox use and temperature.

\section{Discussion}

The present test attempted to assess the preference of foxes for various resting platforms as well as that between resting platforms and the cage floor. As the results showed, the use of resting platforms was low in general because the animals preferred the cage floor. To what extent this reflects the real situation in conventional cage conditions, is worthy of speculation. Two possible deficiencies should be remembered when evaluating the present results. Firstly, previous experiments have shown that platform use is generally rather low in blue foxes, but often varies in terms of season (KoRHONEN and NiEMELÄ 1993a,b). Similarly, the present data from the August-November test period indicated that platform use tended to vary seasonally, showing a decreasing trend towards winter. In Finnish farm conditions, platform use has been observed to be lowest during mid-winter when only from 5 to $15 \%$ of the studied animals typically use them (VALtONEN and Moss 1983, Korhonen and Niemelä 1993b). Thus, it is possible that the time of the year when the present experiments were peformed (i.e. winter) explains the low amount of usage to some extent. Secondly, the location of the various platforms in the test system obviously had an effect on the amount of use. As the results showed, the most commonly used platforms were those located either at the end of the test apparatus or in the mid-section. The problem in the present test system, however, was that it was difficult to conclusively distinquish between the effects of location and type. That would require a test system in which the location of the platforms could be altered.

In farm cage conditions where blue foxes had the possibility to choose between a V-type platform and a nestbox roof, they were found to significantly prefer the latter (KORHONEN and NIEMELÄ 1993b). Likewise in the present test the foxes preferred the roof more than the other platforms. Obviously, something makes the foxes prefer the roof, although the reason is unknown. One explanation may be that the surface area of the nestbox roof was larger than that of the other platforms making it easier for the fox to lie on it. Similarly, a small surface area could explain the low amount of use of the corner type platform during August-November. On the other hand, the present preference results also seem to eliminate 
size as a plausible explanation, because the Vsmall platform was used more than the V-large but the Net-large platform was used more than the Net-small type. It should be noted that the surface area of the V-small type was even smaller than that of the corner type, which for one reason or another was not preferred either before or during the tests. However, as all sizes were not offered in the same location, definitive conclusions about the effect of the platform size require further experiments.

The present results allow us to conclude that the foxes originating from groups where platform use was typically high before the tests, also utilized the platforms more in the tests than foxes from groups with a previous low use. This conclusion appears to hold true only on a group level as no individual relationships between use before and at the tests was found. It is also possible that the scan sampling method, on which the pretest platform data was based, is not totally comparable to the test data based on video recordings, although parallel significant relationships between video and scan sampling data have been previously documented (KORHONEN and NIEMELÄ 1993a, MoNONEN et al. 1993). As a matter of fact, these two methods partly measure different characteristics of platform use. Video data give us the exact amount of time a fox stays on a platform, but the scan sampling method shows in what percentage of sampling observations the fox in question was on the platform.

Because of the low amount of use, the present results actually do not confirm the basis for the previous demands of the European Convention that each fox shall have a resting platform in its cage to lie on and from which to survey the environment. This conclusion is also supported by the recent platform data from cage conditions (HARRI et al. 1991, KorHONEN and NIEMELÄ 1993a,b). It has previously also been mentioned that platforms would be necessary for foxes during the winter to protect them against cold and wind. However, the foxes in the present tests most often slept on the cage floor instead of on the platforms, even on the coldest days. Likewise in cage conditions, platform use by blue foxes has been found to be lowest during winter (KORHONEN and NIEMELÄ 1993b). The low amount of nestbox use, with no relationship to temperature found in the present study, also indicates that the protection of the fur coat already provides foxes with sufficient warmth, and therefore no additional shelters are required.

\section{References}

European Convention 1991. European Convention for the protection of animals kept for farming purposes, Strasbourg 1976, ETS 87. Recommendation Concerning Fur Animals, 25 June 1991. 19 p.

Harri, M., Mononen, J., Korhonen, H. \& HaApanen, K. 1991. A study of the use of resting platforms by farmbred blue foxes. Applied Animal Behavioural Science 30: 125-139.

Jeppesen, L.L. \& Pedersen, V. 1991. Effects of wholeyear nest boxes on cortisol, circulating leucocytes, exploration and agonistic behaviour in the silver fox (Vulpes vulpes). Behavioural Processes 25: 171-177.

Korhonen, H. \& Niemelä, P. 1993a. Use of resting platforms by growing blue foxes. Scientifur 17: 271-276.
- \& Niemelä, P. 1993b. Talvi- ja lisääntymiskauden hyllykoe siniketuilla. Turkistalous 65, 10: 210-218.

Mononen, J., RekilÄ, T. \& Harri, M. 1993. Resting platforms for foxes. NJF seminarium nr 129. Asker, Norge. $12 \mathrm{p}$.

Pedersen, V. \& JePpesen, L.L. 1993. Daytime use of various types of whole-year shelters in farmed silver foxes (Vulpes vulpes) and blue foxes (Alopex lagopus). Applied Animal Behavioural Science 36: 259-273.

SAS 1988. SAS User's Guide. SAS Inst., Inc., Cary, NC.

VAltonen, M. \& Moss, S. 1983. Talvikoppikokeita ketuilla. Turkistalous 55: 634-636.

Manuscript received May 1994 


\title{
SELOSTUS
}

\section{Valintakoe tarhattujen sinikettujen mieltyvyydestä erilaisten makuuhyllyjen ja verkkopohjan välillä}

\author{
Hannu Korhonen ja Paavo Niemelä
}

Maatalouden tutkimuskeskus

Tutkimuksessa selvitettiin sinikettujen mieltyvyyttä erilaisten makuuhyllyjen, pesäkopin ja verkkopohjan välillä testausta varten kehitellyssä valintahäkkiyhdistelmässä. Tulokset osoittivat, että ketut käyttivät hyllyjä vähän, sillä ne viettivăt suurimman osan ajastaan verkkopohjalla. Erilaisista makuuhyllyistä suosituin oli pesäkopin katto. Makuuhyllyn sijainti häkkiyhdistelmässä vaikutti tulokseen, sillä ketut suosivat pääty- ja keskikohdalla olleita hyllyjä. Ketun aiempi kokemus tietystä hyllymallista ennen koetta ei vaikuttanut ketun hyllymallin valintaan valintatestissä. Sen sijaan se, mistä hyllymalliryhmästä kettu oli peräisin, vaikutti hyllyjen käytön määrään testissä. Ulkoilman lämpötila ei vaikuttanut hyllyjen eikä pesäkopin käyttöön. Tulokset viittaavat siihen, etteivät ketut välttämättä tarvitse hyllyjä talvisaikaan. 